\title{
KOMBINASI METODE PENJEMURAN DAN PENGERINGAN TUMPUKAN UNTUK MEMPERBAIKI MUTU BIJI KAKAO KERING
}

\section{COMBINATION OF DRYING AND MECHANICAL DRYING METHODS TO IMPROVE THE QUALITY OF DRIED COCOA BEANS}

\author{
Tya Lestari $^{1 凶}{ }^{\bowtie}$ Leopold O. Nelwan ${ }^{2}$, Emmy Darmawati $^{2}$, Samsudin $^{3}$, Eko Heri Purwanto ${ }^{3}$ \\ ${ }^{1}$ Program Studi Teknologi Pascapanen, Sekolah Pascasarjana, Institut Pertanian Bogor \\ ${ }^{2}$ Departemen Teknik Mesin dan Biosistem, Fakultas Teknologi Pertanian, Institut Pertanian Bogor \\ ${ }^{3}$ Balai Penelitian Tanaman Industri dan Penyegar, Sukabumi \\ $\triangle$ Komunikasi Penulis, email : tya_lestari@apps.ipb.ac.id \\ DOI:http://dx.doi.org/10.23960/jtep-lv9i3.264-275
}

Naskah ini diterima pada 20 Mei 2020; revisi pada 26 Agustus 2020;

disetujui untuk dipublikasikan pada 29 September 2020

\begin{abstract}
Deficiencies in the drying and stacking methods of cocoa beans can be minimized by using a combination of both to improve quality. The purpose of this study was to obtain physicochemical and organoleptic quality information of dried cocoa beans produced by a combination of drying and stack drying. The treatments analyzed were drying 3, 8 and 16 hours followed by mechanical drying using an air flow of $0.05 \mathrm{~m} / \mathrm{s}$ and $0.2 \mathrm{~m} / \mathrm{s}$ at a temperature of $55{ }^{\circ} \mathrm{C}$. As a control is only mechanical drying with two flow rates, up to a water content $<6 \%$. Measurement data were analyzed using descriptive statistics and mean values. The best combination of drying and mechanical drying is found in 8 hours of drying with an air flow velocity of $0.05 \mathrm{~m} / \mathrm{s}$ and $0.2 \mathrm{~m} / \mathrm{s}$. The combination of sun and mechanical drying has no effect on physical parameters namely water content and $p H$, chemical parameters namely total fat and fermentation index. The best color of cocoa beans is produced from a combination of 16 hours of drying with an air flow rate of $0.05 \mathrm{~m} / \mathrm{s}$. The lowest free fatty acid levels come from full mechanical drying with an air flow velocity of $0.05 \mathrm{~m} / \mathrm{s}$ and 3 hours drying in the air flow velocity of $0.2 \mathrm{~m} / \mathrm{s}$. The combination of the best treatment based on the special requirements of SNI 2008 about the quality of defective seeds and organoleptic test results were produced by 8 hours drying air velocity of $0.05 \mathrm{~m} / \mathrm{s}$ and $0.2 \mathrm{~m} / \mathrm{s}$. Included in the IB quality class and has the aroma, texture and color most preferred by panelists.
\end{abstract}

Keywords: air flow, bed dryer, cacao quality, dried cacao, sundrying

\begin{abstract}
ABSTRAK
Kekurangan pada metode penjemuran dan pengering tumpukan biji kakao dapat diminimalisir dengan menggunakan kombinasi keduanya untuk memperbaiki mutu. Tujuan penelitian ini untuk mendapatkan informasi mutu fisikokimia dan organoleptik biji kakao kering yang dihasilkan oleh kombinasi penjemuran dan pengering tumpukan. Perlakuan yang dianalisis adalah penjemuran 3, 8 dan 16 jam dilanjutkan pengeringan mekanis menggunakan aliran udara $0.05 \mathrm{~m} / \mathrm{s}$ dan $0.2 \mathrm{~m} / \mathrm{s}$ dengan suhu $55^{\circ} \mathrm{C}$. Sebagai kontrol adalah pengeringan mekanis saja dengan dua laju aliran tersebut, hingga kadar air $<6 \%$. Data hasil pengukuran dianalisis menggunakan statistik deskriptif dan uji nilai tengah. Kombinasi penjemuran dan pengeringan mekanis terbaik terdapat pada 8 jam jemur dengan kecepatan aliran udara $0.05 \mathrm{~m} / \mathrm{s}$ dan $0.2 \mathrm{~m} / \mathrm{s}$. Kombinasi pengeringan matahari dan mekanis tidak berpengaruh terhadap parameter fisik yaitu kadar air dan $\mathrm{pH}$, parameter kimia yaitu total lemak dan indeks fermentasi. Warna biji kakao terbaik dihasilkan dari kombinasi 16 jam jemur dengan kecepatan aliran udara 0.05 $\mathrm{m} / \mathrm{s}$. Kadar asam lemak bebas yang paling rendah berasal dari pengeringan mekanis penuh dengan kecepatan aliran udara $0.05 \mathrm{~m} / \mathrm{s}$ dan 3 jam jemur kecepatan aliran udara $0.2 \mathrm{~m} / \mathrm{s}$. Kombinasi perlakuan terbaik berdasarkan syarat khusus SNI 2008 tentang mutu biji cacat dan hasil uji organoleptik dihasilkan oleh 8 jam jemur kecepatan aliran udara $0.05 \mathrm{~m} / \mathrm{s}$ dan $0.2 \mathrm{~m} / \mathrm{s}$. Masuk ke dalam golongan mutu IB dan mempunyai aroma, tekstur dan warna yang paling disukai oleh panelis.
\end{abstract}

Kata Kunci: biji kakao, laju aliran udara, mutu kakao, pengering tumpukan, sun drying 


\section{PENDAHULUAN}

Petani kakao umumnya mengeringkan kakaonya dengan cara penjemuran menggunakan cahaya matahari sebagai sumber panas di tempat yang terbuka dan di hampar di lapangan atau lantai jemur. Kendala-kendala yang ditemui dalam penggunaan metode penjemuran seperti kebutuhan lahan yang luas, kontaminasi dengan benda asing serta ketergantungan akan cuaca dapat diatasi dengan menggunakan metode pengeringan mekanis.

Jenis pengering yang digunakan adalah pengeringan tumpukan berbentuk silinder yang memiliki sistem yang sederhana. Pengeringan tumpukan ini mempunyai mekanisme bahan yang akan dikeringkan dalam keadaan diam. Bahan ditempatkan pada bak pengering dan udara dialirkan pada bagian bawah tumpukan yang dihembuskan melewati produk yang dikeringkan (Nainggolan et al. 2013)

Kinerja pengering tumpukan tergantung pada suhu pengeringan dan laju aliran udara. Manalu et al (1998) mengatakan bahwa penggunaan pengering tumpukan dari awal proses pengeringan akan menyebabkan penurunan kualitas karena biji kakao setelah dicuci masih mempunyai lendir atau pulp yang menyebabkan biji kakao saling lengket dan bergerombol sehingga dapat menghambat proses penguapan air dari biji kakao ke udara pengering sehingga memperpanjang waktu pengeringan dan memicu tumbuhnya jamur.

Pada umumnya dilapangan untuk menghemat biaya dan energi digunakan suhu dan aliran udara yang rendah agar didapat laju pengeringan awal yang tidak terlalu tinggi tetapi mempunyai kadar air permukaan yang tinggi. Jika suhu pengeringan yang digunakan tinggi dapat menyebabkan pengeringan yang terlalu cepat sehingga menyebabkan case hardening, sehingga asam volatil tidak dapat keluar melewati kulit biji yang mengeras (Dina et al 2013).

Beberapa praktek umum penjemuran biji kakao yang ada di Indonesia, di jemur terlebih dahulu sekitar 1 hari sebelum pengeringan mekanis dilakukan dengan tujuan agar pengeringan kakao dapat berjalan dengan baik. Beberapa hasil penelitian lain mengenai pengeringan konvektif kakao menunjukkan kualitas pengeringan kakao cukup baik selama laju pengeringannya memadai. Tebal lapisan, suhu serta kecepatan udara sangat mempengaruhi laju pengeringan. Informasi apakah penjemuran yang dilakukan sebelum pengeringan tumpukan dapat memperbaiki kualitas biji kakao kering perlu dilakukan melalui suatu penelitian. Tujuan penelitian ini untuk mendapatkan informasi mutu fisikokimia dan organoleptik biji kakao kering yang dihasilkan oleh kombinasi penjemuran dan pengering tumpukan.

\section{BAHAN DAN METODA}

Penelitian dilakukan pada bulan Juni sampai November 2019 di Laboratorium Terpadu Balai Tanaman Industri dan Penyegar, Sukabumi. Laboratorium Teknik Pengolahan Pangan dan Hasil pertanian (TPPHP) Departemen TMB dan Laboratorium Lapang Siswadhi Supardjo IPB. Alat yang digunakan adalah pengering tumpukan berbentuk silinder dengan skema seperti pada Gambar 1, anemometer, piranometer, termokopel, mortar, oven, desikator, timbangan, gelas beker, erlenmeyer, gelas ukur, pipet tetes, biuret, stirrer, pipet ukur, hot plate, soxhlet dan kertas saring. Bahan yang digunakan adalah 18 kg kakao yang diperoleh dari kebun percobaan Pakuwon yang terletak pada ketinggian 450 mdpl, koordinat $6^{\circ} 49^{\prime} 58.0^{\prime \prime} S$ dan $106^{\circ} 44^{\prime} 28.4 " \mathrm{E}$. Analisis kimia menggunakan $\mathrm{NaOH}, \mathrm{KOH}$, etanol, $\mathrm{HCl}$, akuades dan indikator $\mathrm{pp}$.

\subsection{Parameter Penelitian}

Parameter yang diuji meliputi parameter kimia, fisik dan organoleptik. Pengujian parameter kimia meliputi pengukuran kadar air, kadar lemak total, kadar asam lemak bebas dan indeks fermentasi menggunakan metode Misnawi (2008). Pengujian parameter fisik meliputi perhitungan kadar biji cacat pada kakao, pengukuran $\mathrm{Ph}$ keping biji dan menghitung warna biji kakao kering menggunakan Color Reader Minolta CR-300. Uji organoleptik bubuk kakao dengan uji hdonik menggunakan 30 panelis tidak terlatih. Data dianalisis menggunakan statistik deskriptif dan uji beda nilai tengah. 


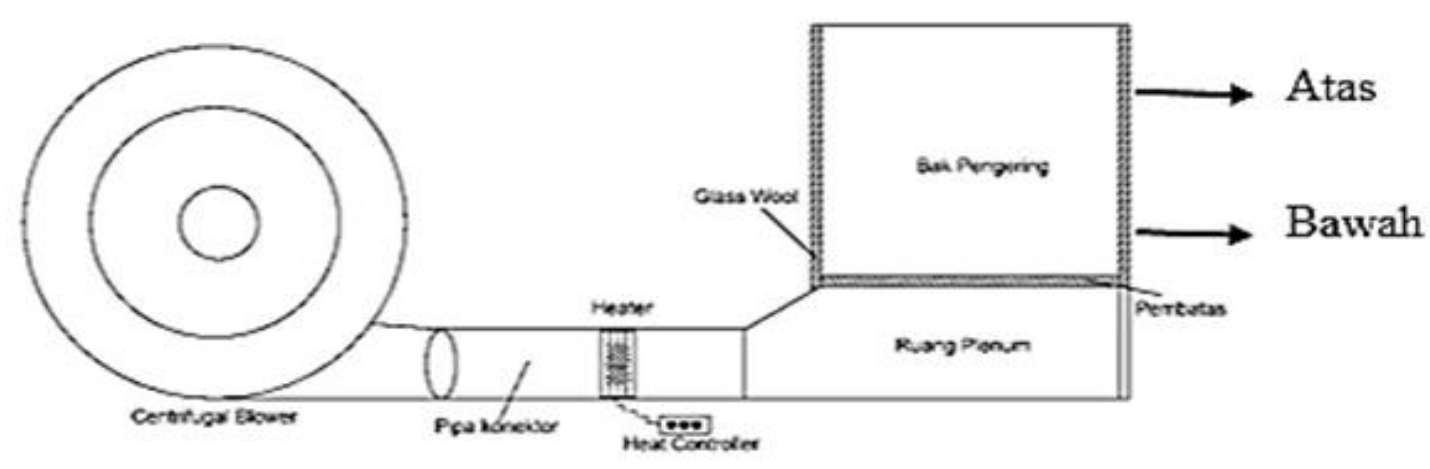

Gambar 1. Pengering Tumpukan dan Titik Pengambilan Sampel

\subsection{Prosedur Penelitian}

Biji kakao basah yang telah dipanen sebanyak $18 \mathrm{~kg}$ difermentasi selama 5 hari di dalam box kayu kemudian dilanjutkan dengan pengeringan dengan perlakuan kombinasi penjemuran dan pengering mekanis. Penjemuran matahari menggunakan terpal pada tempat terbuka. Tebal lapisan biji di atas terpal mencapai $6 \mathrm{~cm} \mathrm{(2-3}$ lapis biji). Metode penjemuran dimulai dari jam 08:00 pagi sampai jam 16:00 sore. Biji kakao yang dijemur dibolak-balik setiap 1-2 jam sekali agar pengeringannya merata. Pengambilan sampel penjemuran diambil dari 2 titik pada terpal. Setelah tahap penjemuran, selanjutnya biji kakao dikeringan menggunakan pengering tumpukan berbentuk silinder pada suhu 55 oC dengan kombinasi perlakuan: P1U1: 3 jam jemur kecepatan aliran udara $0.05 \mathrm{~m} / \mathrm{s}, \mathrm{P} 1 \mathrm{U} 2: 3 \mathrm{jam}$ jemur kecepatan aliran udara $0.2 \mathrm{~m} / \mathrm{s}, \mathrm{P} 2 \mathrm{U} 1 \mathrm{:} 8$ jam jemur kecepatan aliran udara $0.05 \mathrm{~m} / \mathrm{s}$, P2U2: 8 jam jemur kecepatan aliran udara 0.2 $\mathrm{m} / \mathrm{s}, \mathrm{P} 3 \mathrm{U} 1 \mathrm{:} 16$ jam jemur kecepatan aliran udara $0.05 \mathrm{~m} / \mathrm{s}, \mathrm{P} 3 \mathrm{U} 2 \mathrm{~s} 16$ jam jemur kecepatan aliran udara $0.2 \mathrm{~m} / \mathrm{s}$, P4U1: pengeringan mekanis penuh dengan kecepatan aliran udara $0.05 \mathrm{~m} / \mathrm{s}$, P4U2: pengeringan mekanis penuh dengan kecepatan aliran udara $0.2 \mathrm{~m} / \mathrm{s}$ dan kontrol (K) Kontrol hanya dengan penjemuran tanpa menggunakan pengering mesin. Untuk kontrol, penjemuran hari pertama dimulai pada pukul 8:00 sampai dengan pukul 16:00, untuk hari kedua, ketiga, dan kelima dilakukan hal yang sama kecuali hari keeempat pengukuran kadar air hanya dilakukan pada pukul 11:0 dikarenakan turunnya hujan. Setelah selesai, biji kakao disimpan dari jam 16:00 di dalam wadah atau keranjang plastik tanpa penutup dan disimpan pada suhu ruang, dimulai kembali pada jam 08:00 keesokan harinya. Penjemuran dikatakan selesai saat kadar air mencapai $<6 \%$. Laju aliran udara dikontrol menggunakan anemometer, jadi setiap sebelum pengeringan dimulai terlebih dahulu dicek apakah aliran udara sudah sesuai atau belum dengan cara ujung anemometer (panjang seperti bentuk pulpen) akan dimasukkan Kedalam bak pengering jika belum sesuai maka pipa connector di dekat blower akan disesuaikan atau di set ulang dengan mengatur bukan kipas di dekat blower hingga mengasilkan aliran udara yang diinginkan.

Pengeringan tumpukan berbentuk silinder yang digunakan mempunyai diameter $20 \mathrm{~cm}$ dan tinggi $35 \mathrm{~cm}$. Ketebalan tumpukan biji $\pm 10 \mathrm{~cm}$. Setiap 1-2 jam sekali dilakukan pengadukan. Titik pengambilan sampel diambil dari bagian atas dan bawah (Gambar 1) dengan berat masingmasing $\pm 5 \mathrm{~g}$, sampel kemudian dicampur agar merata selanjutnya diukur kadar airnya. Pada masing-masing titik pengambilan sampel dilakukan 2 kali ulangan. Untuk mengukur suhu, digunakan termokopel yang kemudian dihubungkan ke rekorder, pengukuran laju angin menggunakan anemometer dan selama proses penjemuran diukur radiasi matahari menggunakan piranometer. Suhu, kecepatan laju angin, dan radiasi matahari dicatat setiap jam.

\section{HASIL DAN PEMBAHASAN}

\subsection{Kadar air}

Kurva penurunan kadar air kombinasi perlakuan dapat dilihat pada Gambar 2 dan 3. P2U1 dan P2U2 mempunyai waktu pengeringan efektif \pm 23 jam untuk mencapai kadar air $<6 \%$. Pada Tabel 1 dapat dilihat perlakuan terbaik terdapat pada kombinasi kecepatan aliran udara $0.05 \mathrm{~m} /$ 
$\mathrm{s}$ dan $0.2 \mathrm{~m} / \mathrm{s}$ dengan radiasi matahari 260.71 $\mathrm{w} / \mathrm{m} 2$ dan kecepatan angin $0.17 \mathrm{~m} / \mathrm{s}$ hal ini menandakan bahwa penjemuran 8 jam dan dilanjut dengan pengering mekanis sudah efektif untuk mempertahankan mutu biji kakao kering. Pengeringan dihentikan karena kadar air produk sudah dibawah $<6 \%$. Kecepatan aliran udara diukur diatas pengering bak berbentuk silinder menggunakan anemometer dengan kecepatan yang sudah ditetapkan yaitu $0.05 \mathrm{~m} / \mathrm{s}$ dan 0.2 $\mathrm{m} / \mathrm{s}$ dan kecepatan angin merupakan pengukuran laju angin ketika biji kakao dijemur dan kecepatan laju anginnya sesuai dengan kecepatan angin lingkungannya dan tidak di tetapkan seperti kecepatan laju aliran udara pada mesin pengering.

Pada periode awal pengeringan, P2U1 dan P2U2 mempunyai laju penurunan kadar air yaitu 4.5\%/jam pada kecepatan aliran udara $0.2 \mathrm{~m} / \mathrm{s}$ dan $0.05 \mathrm{~m} / \mathrm{s}$. Tingginya laju penurunan kadar air dikarenakan air yang menguap merupakan air bebas yang dapat dengan mudah hilang melalui penjemuran. Setelah penjemuran, dilanjutkan dengan proses pengeringan mekanis dengan kecepatan aliran udara $0.05 \mathrm{~m} / \mathrm{s}$ dan 0.2 $\mathrm{m} / \mathrm{s}$ dengan suhu $55 \mathrm{oC}$ dapat meningkatkan laju penurunan kadar air sehingga air di dalam bahan menguap dengan cepat dan mempersingkat waktu pengeringan. Suhu dan udara pengering akan berpengaruh terhadap laju penguapan air bahan dan mutu pengeringan. Semakin tinggi suhu maka panas yang digunakan untuk penguapan air akan semakin besar sehingga laju penurunan kadar air akan meningkat (Warianti dan Darmanto, 2019). Laju pengeringan awal dan lama pengeringan kombinasi perlakuan terdapat pada Tabel 1 .

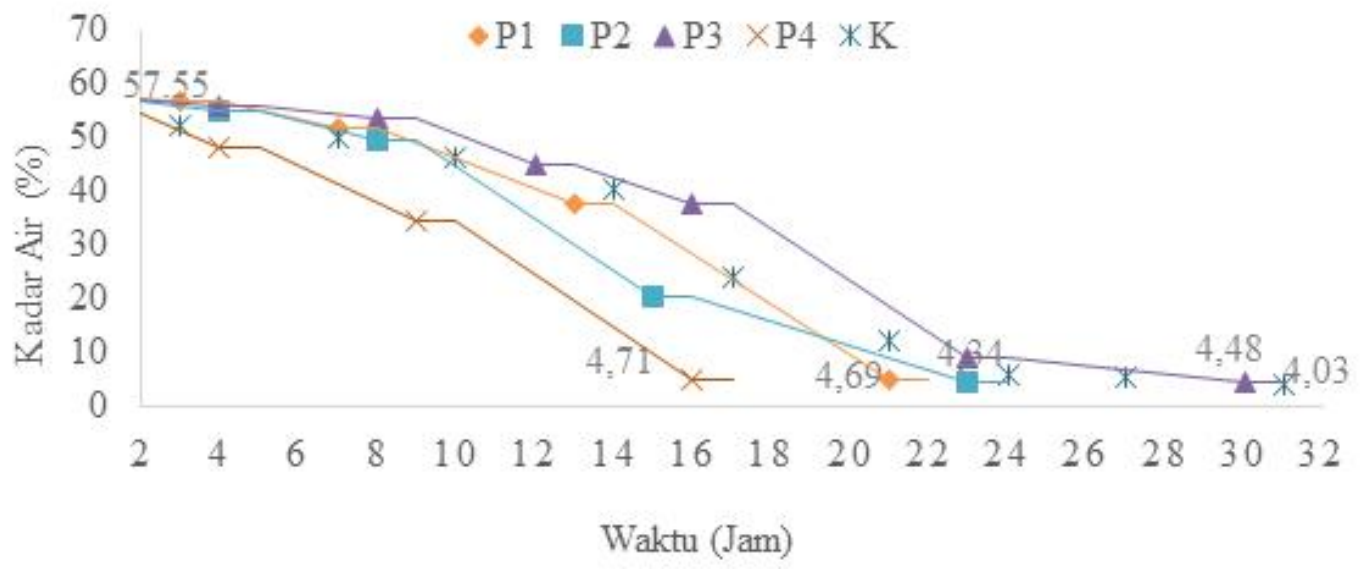

Keterangan: K: kontrol, P1: 3 jam jemur, P2: 8 jam jemur, P3: 16 jam jemur, P4: tanpa jemur

Gambar 2. Penurunan Kadar Air Perlakuan Penjemuran dan Pengeringan Dengan Kecepatan Udara $0.05 \mathrm{~m} / \mathrm{s}$

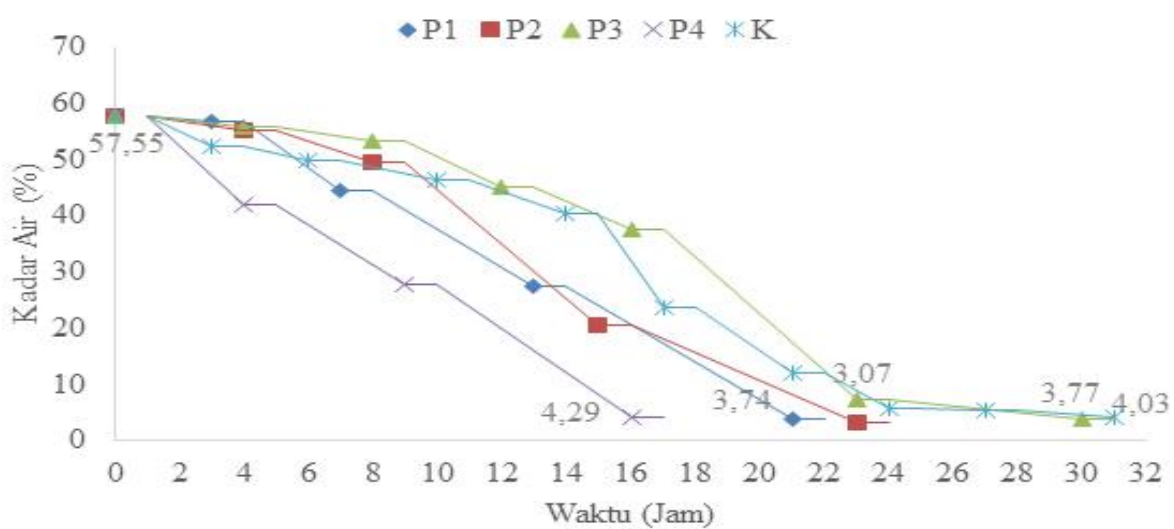

Keterangan: K: kontrol, P1: 3 jam jemur, P2: 8 jam jemur, P3: 16 jam jemur, P4: tanpa jemur

Gambar 3. Penurunan Kadar Air Perlakuan Penjemuran dan Pengeringan Dengan Kecepatan Udara $0.2 \mathrm{~m} / \mathrm{s}$ 
Tabel 1. Laju Pengeringan Awal dan Lama Pengeringan Kombinasi Perlakuan

\begin{tabular}{|c|c|c|c|c|c|}
\hline \multirow[b]{2}{*}{ Perlakuan } & \multicolumn{2}{|c|}{ Periode awal } & \multirow[b]{2}{*}{$\begin{array}{c}\text { Kadar } \\
\text { Air } \\
\text { Akhir } \\
(\%)\end{array}$} & \multirow[b]{2}{*}{$\begin{array}{c}\text { Waktu } \\
\text { Pengeringan } \\
\text { Efektif (jam) }\end{array}$} & \multirow[b]{2}{*}{$\begin{array}{c}\text { Total Waktu } \\
\text { Pengeringan } \\
\text { (jam) }\end{array}$} \\
\hline & $\begin{array}{c}\text { Awal } \\
\text { Pengeringan }\end{array}$ & $\begin{array}{c}\text { Laju } \\
\text { Penurunan } \\
\text { Kadar Air } \\
(\% / \text { jam }) \\
\end{array}$ & & & \\
\hline $\mathrm{K}$ & 7 jam awal & 5.1 & 4.03 & 31 & 110 \\
\hline P1U1 & \multirow{2}{*}{7 jam awal } & 3.9 & 4.98 & \multirow[b]{2}{*}{21} & \multirow{2}{*}{30} \\
\hline P1U2 & & 7.8 & 3.74 & & \\
\hline P2U1 & \multirow{2}{*}{8 jam awal } & 4.5 & 4.34 & \multirow{2}{*}{23} & \multirow{2}{*}{47} \\
\hline P2U2 & & 4.5 & 3.07 & & \\
\hline P3U1 & \multirow{2}{*}{8 jam awal } & 2.6 & 4.48 & \multirow{2}{*}{30} & \multirow{2}{*}{54} \\
\hline P3U2 & & 2.6 & 3.77 & & \\
\hline P4U1 & \multirow{2}{*}{8 jam awal } & 9.1 & 4.71 & \multirow{2}{*}{16} & \multirow{2}{*}{24} \\
\hline P4U2 & & 10.7 & 4.29 & & \\
\hline
\end{tabular}

Keterangan: K: kontrol, P1U1: 3 jam jemur, 0.05 m/s, P1U2: 3 jam jemur, 0.2 m/s, P2U1: 8 jam jemur, 0.05 m/s, P2U2: 8 jam jemur, $0.2 \mathrm{~m} / \mathrm{s}$, P3U1: 16 jam jemur, $0.05 \mathrm{~m} / \mathrm{s}$, P3U2: 16 jam jemur, 0.2m/s, P4U1: Tanpa jemur, $0.05 \mathrm{~m} / \mathrm{s}, \mathrm{P} 4 \mathrm{U} 2$ : Tanpa jemur, $0.2 \mathrm{~m} / \mathrm{s}$

Dilain sisi, perlakuan P4 adalah perlakuan pengeringan menggunakan pengering mekanis penuh hingga mencapai kadar air akhir $<6 \%$. Perlakuan P4U1 dan P4U2 mempunyai laju penurunan kadar air awal yang besar dibandingkan dengan semua perlakuan, hal ini dikarenakan dari awal proses pengeringan langsung menggunakan mesin, dimana kandungan air bebas di dalam bahan lebih tinggi dan lebih mudah untuk menguap. Selain itu, suhu $55^{\circ} \mathrm{C}$ yang digunakan pada alat pengering dapat menyebabkan tekanan uap menjadi lebih besar sehingga terjadi perpindahan air dari kakao ke lingkungan dan air lebih mudah untuk diuapkan yang berpengaruh pada laju penurunan kadar air semakin cepat. Udara yang bergerak dan mempunyai gerakan yang tinggi selain dapat mengambil uap air juga akan menghilangkan uap air tersebut dari permukaan bahan pangan, sehingga akan mencegah terjadinya atmosfir jenuh yang akan memperlambat penghilangan air. Apabila aliran udara disekitar tempat pengeringan berjalan dengan baik, proses pengeringan akan semakin cepat, yaitu semakin mudah dan semakin cepat uap air terbawa dan teruapkan.

Kontrol memiliki laju penurunan 5.1\%/jam dimana kadar air bebas menguap secara langsung dalam jumlah besar dan semakin hari semakin menurun, hal ini sesuai dengan Choirunnisa et al., (2017) yang mengatakan bahwa diawal proses pengeringan kadar air bebas menguap secara langsung dalam jumlah yang besar kemudian pada titik tertentu laju pengeringan akan menurun hingga proses pengeringan selesai, dibutuhkan total waktu penjemuran efektif selama \pm 31 jam dari total \pm 110 jam $( \pm 5$ hari) penjemuran.

Hasil analisis kadar air pada Gambar 4 dapat disimpulkan bahwa perlakuan dengan kecepatan aliran udara yang lebih tinggi menghasilkan kadar air yang lebih rendah dikarenakan semakin cepat aliran udara maka semakin banyak air yang menguap. Adanya perbedaan kadar air akhir dengan kadar air setelah perhitungan laju penurunan kadar air disebabkan oleh adanya pengaruh faktor penyimpanan dan jeda waktu analisis kadar air akhir dilakukan kembali.

P4U1 mempunyai kadar air yang lebih tinggi dibandingkan perlakuan lainnya karena tidak mengalami penjemuran dimana pada saat proses penjemuran terjadi penurunan kadar air bebas bahan, tetapi langsung menggunakan mesin pengering dengan kecepatan aliran udara yang rendah yang menyebabkan penurunan dan penguapan kadar air lebih lambat sehingga kadar airnya relatif lebih tinggi dibandingkan perlakuan lain. Setelah dikeringkan biji kakao diikat menggunakan plastik dan disimpan pada suhu ruang. Lembapnya udara pada malam hari dan kakao kering bersifat higroskopis yang kadar airnya dapat berubah sesuai dengan kelembaban udara sekelilingnya, diduga dapat kembali memicu peningkatan kadar air. Setelah 


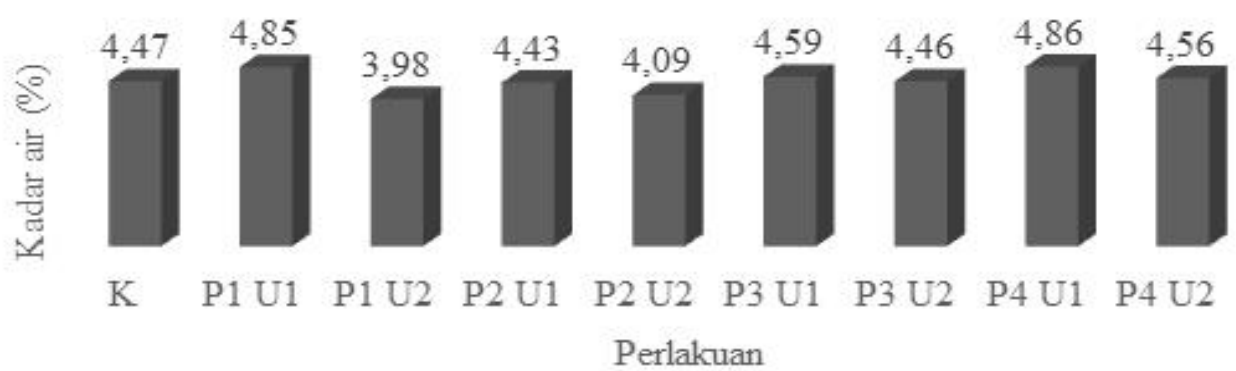

Keterangan: K: kontrol, P1U1: 3 jam jemur, 0.05 m/s, P1U2: 3 jam jemur, 0.2 m/s, P2U1: 8 jam jemur, 0.05 m/s, P2U2: 8 jam jemur, $0.2 \mathrm{~m} / \mathrm{s}$, P3U1: 16 jam jemur, $0.05 \mathrm{~m} / \mathrm{s}$, P3U2: 16 jam jemur, 0.2m/s, P4U1: Tanpa jemur, 0.05 $\mathrm{m} / \mathrm{s}, \mathrm{P} 4 \mathrm{U} 2$ : Tanpa jemur, $0.2 \mathrm{~m} / \mathrm{s}$

Gambar 4. Hasil Analisis Kadar Air Kombinasi Perlakuan

P4U1, menyusul P1U1 mempunyai kadar air yang tinggi. Hal ini disebabkan kecepatan udara pengering yang rendah selain itu adanya pengaruh penyimpanan juga berpengaruh pada kadar air akhir biji kakao penyimpanan biji kakao pada malam hari menggunakan wadah plastik yang tidak ditutup menyebabkan biji kakao menyerap air yang ada diruang penyimpanan sehingga biji kakao mengalami kesetimbangan dengan kadar air lingkungan sekitar yang berakibat pada tingginya kandungan kadar air.

\subsection{Warna Biji Kakao}

Yang dimaksudkan dengan warna biji kakao disini adalah warna permukaan biji kakao menggunakan colour reader Minolta CR-300. Pengaruh perlakuan tidak berbeda nyata pada warna yang dihasilkan karena warna yang dihasilkan dipengaruhi oleh indeks fermentasi juga dimana indeks fermentasi pada kakao sudah $>1$ yang artinya fermentasi sudah sempurna sehingga berpengaruh pada warna kakao yang dihasilkan. Peranan warna sangat nyata karena umumnya konsumen akan mendapatkan kesan pertama, baik suka atau tidak suka terhadap suatu produk pangan dari warnanya, Andarwulan et al., (2011). Dari hasil analisis, dapat dilihat pada Tabel 2 bahwa tidak ada perbedaan antar semua perlakuan yang dapat dilihat dari tercapainya semua indeks fermentasi yang lebih dari 1, yang dapat diartikan bahwa fermentasi telah cukup mendegradasi pigmen antosianin yang menyebabkan perubahan warna dari ungu menjadi coklat. Protein dan peptida membentuk komplek dengan senyawa polifenol menghasilkan warna coklat atau coklat-ungu (Beckett et al, 2009). Terbentuknya warna coklat khas pada biji kakao dimungkinkan karena adanya peristiwa pencoklatan non enzimatis yang terjadi pada proses pengeringan, yaitu karamelisasi dari senyawa polihidroksi karbonil (gula reduksi) yang bila dipanaskan pada suhu tinggi akan terjadi perubahan flavor, warna dan bau dari gulanya, dan jika pemanasan berlanjut akan terbentuk zat berasa pahit, warna hitam dan berasa terbakar.

\section{3. pH Biji Kakao}

Kualitas biji kakao hasil fermentasi ditentukan terutama oleh keasaman $(\mathrm{pH})$ dan keasaman biji selama fermentasi. Hasil analisis $\mathrm{pH}$ kakao pada Tabel 2 menunjukkan tidak ada perbedaan pada semua perlakuan dan $\mathrm{pH}$ yang dihasilkan sesuai dengan yang diinginkan yaitu pada range 5.085.18. Hal ini dikarenakan penggunaan suhu mesin pengering yang tinggi yaitu $55^{\circ} \mathrm{C}$ akan menguapkan asam organik dalam biji dalam jumlah yang makin banyak (Rahmadewi \& Darmadji, 2018), selain itu selama proses pengeringan senyawa asam volatil menguap bersama dengan menguapnya air dan selama pengeringan udara dari luar akan masuk melalui kulit biji sehingga cairan sel yang terdapat di bawah kulit biji menguap dan secara perlahan kotiledon akan berubah menjadi cokelat (Haryadi \& Supriyanto, 2012). Nilai pH yang rendah ini diakibatkan proses difusi asam yang diproduksi bakteri asam laktat dan asam asetat ke dalam biji selama proses fermentasi yang dilakukan selama 5 hari dengan pembalikan setiap 1 kali 24 jam yaitu pada hari ke 2 dan ke 4 .

\subsection{Kadar Biji Cacat (Berjamur, Ungu (Slaty), Berserangga, Berkecambah)}

Uji belah dilakukan untuk mengamati perubahan warna biji kakao. Perubahan warna disebabkan oleh kandungan senyawa polifenol pada biji 
kakao. Dengan teroksidasinya senyawa polifenol seiring lamanya fermentasi, warna keping biji yang semula ungu berubah menjadi coklat.

Hasil analisis pada Tabel 2 perlakuan P1U1 merupakan perlakuan dengan biji berkapang atau berjamur yang paling tinggi dan mempunyai biji ungu yang rendah. Hal ini dikarenakan P1U1 merupakan perlakuan yang paling dahulu dilakukan proses pengeringannya dibandingkan perlakuan lainnya. Selain itu, P1U1 merupakan perlakuan yang paling lama disimpan pada suhu ruang, karena udara pada malam hari lebih lembab, kakao kering bersifat higroskopis sehingga kadar air permukaan dapat berubah sesuai dengan kelembaban udara sekelilingnya yang memungkinkan terjadi pertumbuhan jamur (Ariyanti, 2017). Selanjutnya P3U1 dan P3U2 yang dikarenakan perlakuan P3 dijemur selama 16 jam atau 2 hari, setiap selesai penjemuran biji kakao disimpan menggunakan wadah plastik, tidak ditutup dan disimpan pada suhu ruang yang jika malam hari udara akan lembab dan berpotensi adanya pertumbuhan jamur atau kapang.

Berdasarkan SNI 2008 tentang mutu khusus kakao yang dapat dilihat pada Tabel 3, perlakuan kontrol, P1U2, P2U1 \& P2U2, P4U1 \& P4U2 termasuk kedalam golongan mutu IB, sedangkan P1U1, P3U1 \& P3U2 termasuk ke dalam golongan mutu IIB. Kadar biji ungu (slaty) yang paling banyak terdapat pada perlakuan kontrol dan diikuti oleh perlakuan P3, hal ini kemungkinan proses pengadukan pada saat fermentasi di dalam box tidak merata ke seluruh biji kakao sehingga menyebabkan adanya biji slaty (warna ungu agak keabu-abuan). Untuk persentase kadar biji ungu menurut SNI 2008, semua perlakuan masuk kedalam golongan mutu IB yaitu mutu I Bulk cocoa (kakao lindak).

\subsection{Kadar Lemak Total}

Pada umumnya persentase lemak kakao Indonesia berada pada kisaran 53\% (Gu et al., 2013). Lemak kakao adalah lemak yang diperoleh dari biji kakao (nibs) yang difermentasi atau tidak difermentasi dengan cara mekanis dengan menggunakan alat press hidrolik atau expeller atau dengan cara kimiawi menggunakan pelarut organik. Dari hasil analisis kadar lemak total pada Gambar 5 diperoleh data yang menunjukkan bahwa tidak ada perbedaan yang signifikan pada setiap perlakuan. Pada penelitian ini, kakao yang digunakan mempunyai kadar lemak yang lebih rendah jika dibandingkan dengan literatur hal ini disebabkan

Tabel 2. Pengaruh Perlakuan Terhadap Parameter Fisik Biji Kakao

\begin{tabular}{lcccccc}
\hline Perlakuan & $\begin{array}{c}\text { Warna Biji } \\
\text { Kakao }\end{array}$ & pH & \multicolumn{3}{c}{ Kadar Biji Cacat (\%) } \\
\cline { 4 - 7 } & $1.34 \pm 0.05^{\text {a }}$ & 5.09 & 1.33 & 0 & 2.00 & 0 \\
\hline K & $1.45 \pm 0.01^{\mathrm{b}}$ & 5.13 & 2.67 & 0 & 0.67 & 0 \\
P1 U1 & $1.37 \pm 0.07$ ab & 5.09 & 1.33 & 0 & 1.00 & 0 \\
P1 U2 & $1.40 \pm 0.01^{\text {ab }}$ & 5.08 & 1.33 & 0 & 1.00 & 0 \\
P2 U1 & $1.41 \pm 0.01^{\text {ab }}$ & 5.1 & 1.33 & 0 & 1.33 & 0 \\
P2 U2 & $1.46 \pm 0.03^{\mathrm{b}}$ & 5.11 & 2.33 & 0 & 1.67 & 0 \\
P3 U1 & $1.35 \pm 0.03^{\mathrm{a}}$ & 5.11 & 2.33 & 0 & 1.67 & 0 \\
P3 U2 & $1.39 \pm 0.07$ ab & 5.18 & 1.33 & 0 & 0.67 & 0 \\
P4 U1 & $1.40 \pm 0.04$ ab & 5.13 & 1.33 & 0 & 0.67 & 0 \\
P4 U2 &
\end{tabular}

Keterangan: K: kontrol, P1U1: 3 jam jemur, 0.05 m/s, P1U2: 3 jam jemur, 0.2 m/s, P2U1: 8 jam jemur, 0.05 m/s, P2U2: 8 jam jemur, $0.2 \mathrm{~m} / \mathrm{s}$, P3U1: 16 jam jemur, 0.05 m/s, P3U2: 16 jam jemur, $0.2 \mathrm{~m} / \mathrm{s}$, P4U1: Tanpa jemur, 0.05 $\mathrm{m} / \mathrm{s}, \mathrm{P} 4 \mathrm{U} 2:$ Tanpa jemur, $0.2 \mathrm{~m} / \mathrm{s}$

Tabel 3. Persyaratan Khusus Biji Kakao

\begin{tabular}{ccccccc}
\hline $\begin{array}{c}\text { Kakao Mulia } \\
\text { (Fine Cocoa) }\end{array}$ & $\begin{array}{c}\text { Kakao Lindak } \\
\text { (Bulk Cocoa) }\end{array}$ & $\begin{array}{c}\text { Kadar Biji } \\
\text { Berjamur } \\
\text { (biji/biji) }\end{array}$ & $\begin{array}{c}\text { Kadar Biji } \\
\text { Slaty } \\
\text { (biji/biji) }\end{array}$ & $\begin{array}{c}\text { Kadar Biji } \\
\text { Berserangga } \\
\text { (biji/biji) }\end{array}$ & $\begin{array}{c}\text { Kadar Kotoran } \\
\text { Waste (biji/biji) }\end{array}$ & $\begin{array}{c}\text { Kadar Biji } \\
\text { Berkecambah } \\
\text { (biji/biji) }\end{array}$ \\
\hline I-F & I-B & Maks 2 & Maks 3 & Maks 1 & Maks 1.5 & Maks 2 \\
II-F & II-B & Maks 4 & Maks 8 & Maks 2 & Maks 2.0 & Maks 3 \\
III-F & III-B & Maks 4 & Maks 20 & Maks 2 & Maks 3.0 & Maks 3 \\
\hline
\end{tabular}


karena buah kakao dipanen dalam kondisi yang belum masak sempurna (buah terlalu muda) sehingga berakibat pada rendahnya kandungan lemak. Faktor musim juga berpengaruh untuk menentukan kandungan lemak kakao, biji kakao yang berasal dari pembuahan musim hujan umumnya mempunyai kadar lemak lebih tinggi sedangkan kakao yang digunakan pada penelitian ini berasal dari pembuahan musim panas sehingga kadar lemak total yang dihasilkan rendah (Ristanti et al, 2016).

Liyanda et al., (2012) mengatakan bahwa ketinggian tempat mempunyai pengaruh terhadap produksi dan kadar lemak kakao. Semakin tinggi tempat penanaman kakao suhu semakin rendah sehingga semakin tinggi pula kadar lemak kakao yang dihasilkan dan menurut Wahyudi et al,, (2013), ukuran berat dan kadar lemak biji kakao sangat dipengaruhi oleh faktor genetik (klon) tanaman, kondisi lingkungan (musim) selama perkembangan buah, perlakuan agronomis dan cara pengolahan, sedangkan karakter fisik biji kakao pasca pengolahan seperti kadar air, tingkat fermentasi dan kadar kulit berpengaruh pada rendemen lemak biji kakao. Komponen penyusun lemak relatif tidak dipengaruhi proses pengolahan biji kakao tetapi dipengaruhi oleh 1) tingkat kematangan biji waktu dipanen, 2) klon, 3) Tanaman tempat tumbuh dan 4) musim panen.

\subsection{Kadar Asam Lemak Bebas}

Asam lemak bebas adalah asam lemak yang berada dalam keadaan bebas, tidak terikat sebagai trigliserida. Keberadaan asam lemak bebas (FFA) di dalam lemak kakao harus dihindari karena merupakan salah satu indikator kerusakan mutu. Kadar asam lemak bebas seharusnya kurang dari 1\% (Mulato et al, 2010). Menurut Codex Alimentarius Commission batas kadar asam lemak bebas dalam biji kakao maksimal $1.75 \%$.

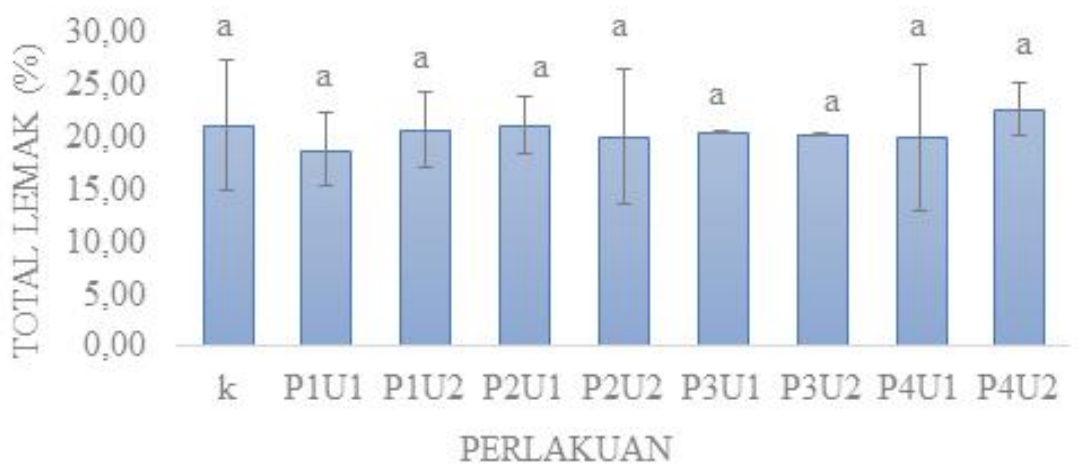

Keterangan: K: kontrol, P1U1: 3 jam jemur, 0.05 m/s, P1U2: 3 jam jemur, 0.2 m/s, P2U1: 8 jam jemur, 0.05 m/s, P2U2: 8 jam jemur, 0.2 m/s, P3U1: 16 jam jemur, 0.05 m/s, P3U2: 16 jam jemur, $0.2 \mathrm{~m} / \mathrm{s}$, P4U1: Tanpa jemur, 0.05 $\mathrm{m} / \mathrm{s}, \mathrm{P} 4 \mathrm{U} 2$ : Tanpa jemur, $0.2 \mathrm{~m} / \mathrm{s}$

Gambar 5. Pengaruh Perlakuan Terhadap Lemak Total

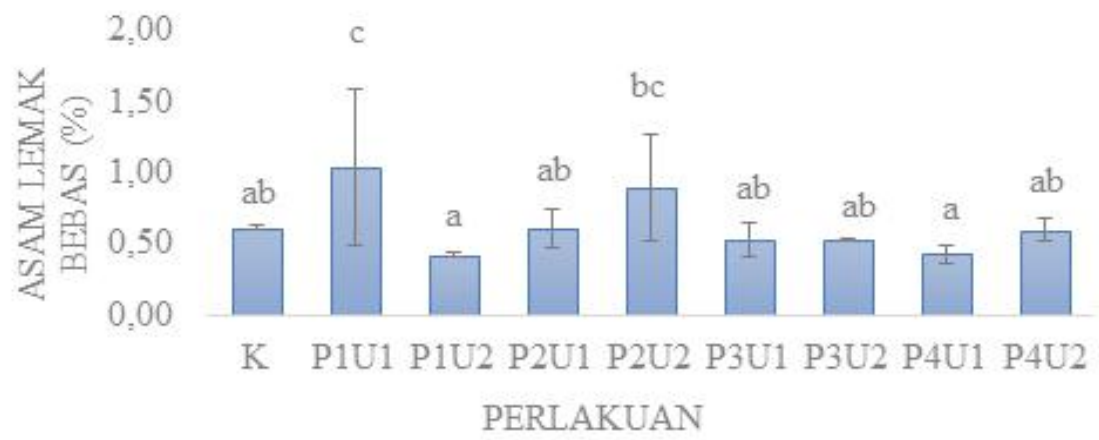

Keterangan: K: kontrol, P1U1: 3 jam jemur, 0.05 m/s, P1U2: 3 jam jemur, 0.2 m/s, P2U1: 8 jam jemur, 0.05 m/s, P2U2: 8 jam jemur, $0.2 \mathrm{~m} / \mathrm{s}$, P3U1: 16 jam jemur, $0.05 \mathrm{~m} / \mathrm{s}$, P3U2: 16 jam jemur, $0.2 \mathrm{~m} / \mathrm{s}$, P4U1: Tanpa jemur, 0.05 $\mathrm{m} / \mathrm{s}, \mathrm{P} 4 \mathrm{U} 2$ : Tanpa jemur, $0.2 \mathrm{~m} / \mathrm{s}$

Gambar 6. Pengaruh Perlakuan Terhadap Asam Lemak Bebas 
Menurut Ketaren (2008) asam lemak bebas yang terbentuk dalam produk makanan terdapat dalam jumlah kecil dan sebagian besar terikat dalam bentuk ester trigliserida. Reaksi hidrolisis dan oksidasi lemak akan mengakibatkan ketengikan yang menghasilkan flavor dan bau tengik pada makanan yang mengandung lemak. Dari hasil analisis pada Gambar 6, kadar asam lemak bebas yang paling tinggi terdapat pada perlakuan P1U1 hal ini dikarenakan perlakuan P1U1 mempunyai kadar air dan kadar biji berkapang (mouldy) yang terlihat secara visual yang tinggi dibandingkan dengan perlakuan lainnya.

Prakash (2002) mengatakan bahwa biji kakao dengan kandungan air tinggi mudah diserang oleh mikroba. Mikroorganisme menghasilkan enzim Lipase yang berfungsi sebagai biokatalisator reaksi hidrolisis minyak yang akan menghasilkan gliserol dan asam lemak bebas (Maimun et al., 2017). Reaksi hidrolisis merupakan reaksi konversi menjadi asam lemak dan gliserol dengan adanya air dan enzim lipase (Dewi et al., 2015). Satu molekul trigliserida (yang dapat berupa minyak atau lemak) akan bereaksi dengan 3 molekul air, menghasilkan 3 molekul asam lemak dan 1 molekul gliserol yang ditandai dengan meningkatnya kandungan asam lemak bebas sebagai hasil hidrolisinya. Semakin tinggi kandungan air dalam bahan pangan, maka semakin tinggi kadar ALB yang terbentuk karena reaksi hidrolisis berlangsung semakin cepat (Pahan, 2015).

\subsection{Indeks Fermentasi}

Indeks fermentasi adalah perbandingan absorbansi pada panjang gelombang $460 \mathrm{~nm}$ (flavonoid kompleks) dan 530 nm (anthocyanin). Indeks fermentasi merupakan parameter untuk mengukur derajat fermentasi biji kakao dengan cara mengukur perubahan warna dari ungu menjadi cokelat. Indikator terjadinya fermentasi sempurna dilihat dari angka IF dimana jika terfermentasi sempurna diperoleh angka IF satu atau lebih. Biji kakao kering yang telah difermentasi memiliki Indeks Fermentasi dengan nilai IF e" 1, sedangkan untuk biji kakao tanpa fermentasi mempunyai nilai IF $<1$.

Data yang diperoleh pada Gambar 7 menunjukkan secara keseluruhan semua perlakuan mempunyai indeks fermentasi lebih dari 1, hal ini berarti fermentasi telah mencukupi untuk mendegradasi pigmen antosianin. Anthocyanin yang menyebabkan warna ungu terhidrolisis menjadi cyanidin dan gula oleh enzim glikosidase. Degradasi anthocyanin menyebabkan perubahan warna dari ungu menjadi coklat. Protein dan peptida membentuk komplek dengan senyawa polifenol menghasilkan warna coklat atau coklat-ungu. Sukrosa diubah oleh invertase menjadi gula reduksi. Protein terhidrolisa oleh enzim peptidase menjadi oligopeptida dan asam amino. Prekursor aroma kakao ini terlibat dalam reaksi maillard selama penyangraian untuk membentuk senyawa aroma kakao (Beckett et al., 2009). Bersamaan dengan berlangsungnya destruksi anthocyanin, terbentuk cairan berwarna coklat dari senyawa flavonoid komplek pada ruang antara kulit biji dan keping biji.. Hal inilah yang digunakan sebagai parameter Indeks Fermentasi (IF), dengan nilai berupa rasio antara kadar flavonoid kompleks (coklat) dan kadar

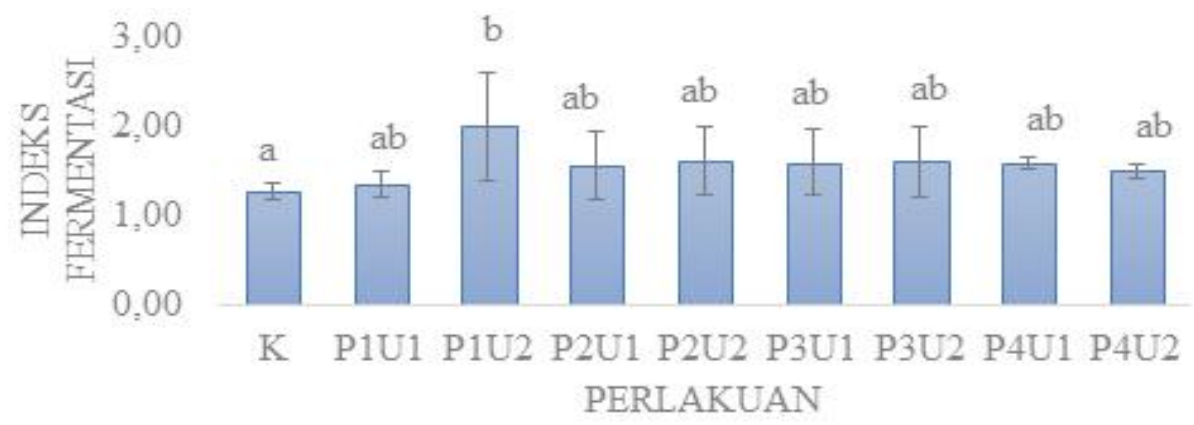

Keterangan: K: kontrol, P1U1: 3 jam jemur, 0.05 m/s, P1U2: 3 jam jemur, 0.2 m/s, P2U1: 8 jam jemur, 0.05 m/s, P2U2: 8 jam jemur, 0.2 m/s, P3U1: 16 jam jemur, 0.05 m/s, P3U2: 16 jam jemur, 0.2m/s, P4U1: Tanpa jemur, 0.05 $\mathrm{m} / \mathrm{s}, \mathrm{P} 4 \mathrm{U} 2$ : Tanpa jemur, $0.2 \mathrm{~m} / \mathrm{s}$

Gambar 7. Pengaruh Perlakuan Terhadap Indeks Fermentasi 
anthocyanin (ungu Waktu fermentasi yang lebih lama memungkinkan proses destruksi anthocyanin dan pembentukan senyawa berwarna coklat menjadi lebih sempurna sehingga nilai IF lebih tinggi (Utami, 2018).

\subsection{Uji Organoleptik}

Hasil uji organoleptik rasa bubuk kakao menurut panelis didapatkan hasil bahwa setiap perlakuan tidak memberikan pengaruh yang nyata. Hasil uji organoleptik dapat dilihat pada Gambar 8.

\subsubsection{Rasa}

Rasa adalah hal yang terpenting pada sifat organoleptik suatu produk, hasil uji organoleptik rasa pada bubuk kakao menunjukkan perlakuan P1U1 dengan rata-rata 3.4 yaitu agak tidak suka, mempunyai nilai rendah atau rasa yang paling tidak disukai oleh panelis, hal ini dikarenakan pada perlakuan P1U1 mempunyai rasa yang agak tengik karena mempunyai kadar biji berjamur yang lebih tinggi dibandingkan dengan perlakuan lain sehingga berkontribusi terhadap rasa rancidity yang dihasilkan.

Perlakuan P3U2 mempunyai nilai tertinggi dan rasa yang paling disukai oleh panelis dengan nilai rata-rata 4.73 mendekati suka hal ini disebabkan biji kakao yang digunakan adalah biji kakao fermentasi (full fermented) dengan suhu penyangraian $120 \mathrm{oC}$ rasa pahit pada biji kakao akan menghilang setelah di sangrai sehingga mengembangkan cita rasa dan aroma khas cokelat.

\subsubsection{Aroma}

Perlakuan P2U2 dengan rata-rata 5.13 berada dalam range suka, mempunyai aroma yang paling disukai hal ini disebabkan kadar air P2U2 termasuk rendah dibandingkan dengan perlakuan lainnya, sehingga menurut Ramlah (2016) Biji kakao yang telah difermentasi dan dikeringkan dengan baik mengandung cukup banyak senyawa calon pembentuk citarasa dan aroma khas cokelat antara lain asam amino dan gula reduksi. Jika dipanaskan pada suhu dan waktu yang cukup, keduanya akan bereaksi membentuk senyawa maillard (reaksi pembentukan rasa dan aroma).

Selain itu waktu fermentasi berpengaruh terhadap aroma yang dihasilkan. Semakin lama fermentasi aroma khas biji kakao yang dihasilkan semakin kuat (Hayati et al., 2012). P1U1 dengan rata-rata 4.2 mempunyai nilai rendah atau rasa yang paling tidak disukai oleh panelis, hal ini dikarenakan perlakuan P1 mempunyai aroma yang agak tengik dibandingkan dengan perlakuan lain yang disebabkan oleh perlakuan P1 mempunyai kadar biji berjamur yang lebih tinggi dibandingkan dengan perlakuan lain.

\subsubsection{Warna}

Faktor yang berperan dalam pembentukan warna yaitu waktu fermentasi dan lama pengeringan. Dari hasil penelitian ini dapat dilihat bahwa pada setiap perlakuan warna tidak berbeda nyata terhadap bubuk kakao yang dihasilkan, hal ini

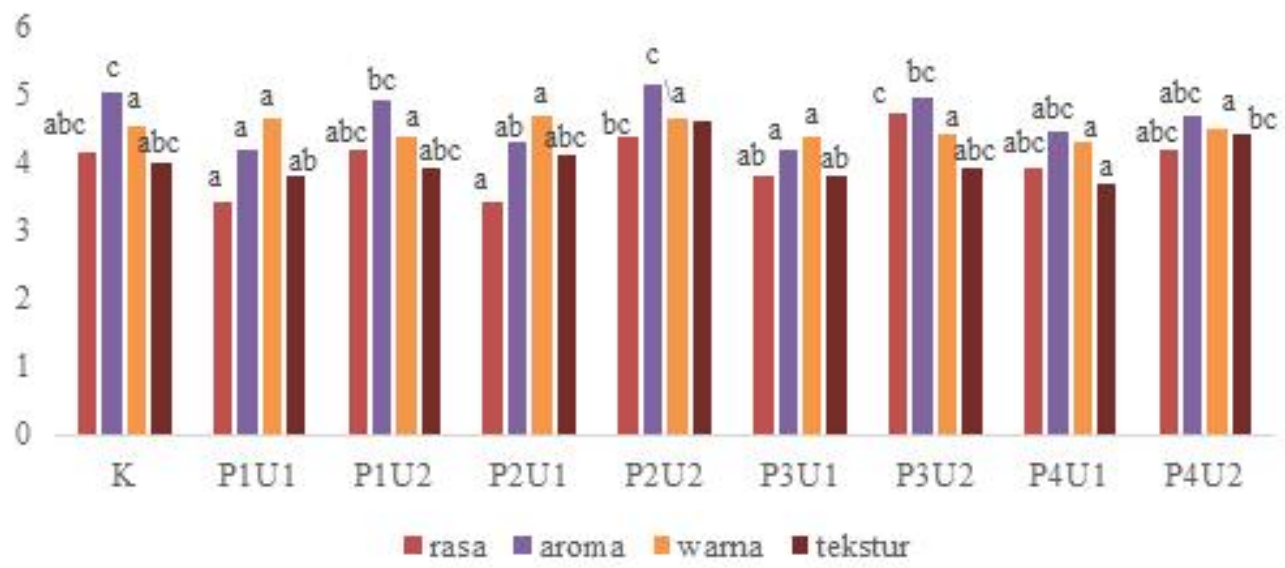

Keterangan: K: kontrol, P1U1: 3 jam jemur, 0.05 m/s, P1U2: 3 jam jemur, 0.2 m/s, P2U1: 8 jam jemur, 0.05 m/s, P2U2: 8 jam jemur, $0.2 \mathrm{~m} / \mathrm{s}$, P3U1: 16 jam jemur, $0.05 \mathrm{~m} / \mathrm{s}$, P3U2: 16 jam jemur, 0.2m/s, P4U1: Tanpa jemur, 0.05 $\mathrm{m} / \mathrm{s}, \mathrm{P} 4 \mathrm{U} 2$ : Tanpa jemur, $0.2 \mathrm{~m} / \mathrm{s}$

Gambar 8. Hasil Uji Organoleptik Kombinasi Perlakuan 
disebabkan karena biji kakao mempunyai polifenol, pada proses fermentasi terjadi penguraian senyawa polifenol semakin tinggi kandungan polifenol dalam biji akan mendorong terjadi reaksi maillard, dengan bantuan polifinol oksidase menghasilkan warna kakao (Puziah, 2005) yang terjadi pada saat pengeringan.

Pada penelitian ini P4 merupakan perlakuan yang memiliki nilai warna paling rendah dibanding perlakuan lain, hal ini dikarenakan P4 tidak mengalami penjemuran, langsung menggunakan mesin pengering. Melalui proses penjemuran ini akan diperoleh warna biji kakao coklat kemerahan dan tampak lebih cemerlang. Warna dan kenampakan yang demikian inilah yang diharapkan pada biji kakao. Sehingga ketika biji kakao dijadikan bubuk akan berpengaruh pada warna yang dihasilkan.

\subsubsection{Tekstur}

Pada penelitian ini tekstur yang digunakan adalah dengan penginderaan yang berasal dari sentuhan menggunakan ujung jari tangan. Dari hasil uji organoleptik yang di dapat perlakuan P2U2 paling disukai dan mempunyai nilai tinggi dengan rata-rata 4.6 berada dalam range suka hal ini disebabkan oleh perlakuan P2U2 memiliki kadar air yang rendah sehingga teksturnya halus ketika diletakkan diantara permukaan dalam ibu jari, telunjuk, jari tengah. Sedangkan tekstur yang tidak disukai ada pada perlakuan P4U1 karena memiliki kadar air yang tinggi sehingga ketika diletakkan diantara permukaan dalam ibu jari, telunjuk, jari tengah teksturnya sedikit menggumpal.

\section{KESIMPULAN DAN SARAN}

\subsection{Kesimpulan}

Disimpulkan bahwa kombinasi penjemuran dan pengeringan tumpukan terbaik terdapat pada perlakuan 8 jam jemur dengan kecepatan aliran udara $0.05 \mathrm{~m} / \mathrm{s}$ dan $0.2 \mathrm{~m} / \mathrm{s}$. Kombinasi perlakuan tidak berpengaruh terhadap parameter fisik berupa kadar air dan $\mathrm{pH}$, parameter kimia berupa total lemak dan indeks fermentasi. Warna biji kakao terbaik dihasilkan dari kombinasi perlakuan 16 jam jemur kecepatan udara 0.05 $\mathrm{m} / \mathrm{s}$. Kadar asam lemak bebas yang paling rendah berasal dari perlakuan full mekanis kecepatan aliran udara $0.05 \mathrm{~m} / \mathrm{s}$ dan 3 jam jemur kecepatan aliran udara $0.2 \mathrm{~m} / \mathrm{s}$. Kombinasi perlakuan terbaik berdasarkan syarat khusus SNI 2008 tentang mutu biji cacat dan hasil uji organoleptik menunjukkan perlakuan 8 jam jemur kecepatan aliran udara $0.05 \mathrm{~m} / \mathrm{s}$ dan $0.2 \mathrm{~m} / \mathrm{s}$ masuk kedalam golongan mutu IB dan mempunyai aroma, tekstur dan warna yang paling disukai oleh panelis.

\subsection{Saran}

Perlu dilakukan penelitian lanjutan untuk mengetahui laju kecepatan aliran udara dan suhu yang tepat sehingga bisa diaplikasikan untuk mendapatkan mutu yang lebih baik.

\section{DAFTAR PUSTAKA}

Andarwulan, N., Kusnandar, F., Herawati, D. 2011. Analisis Pangan. PT Dian Rakyat Jakarta.

Ariyanti, M. 2017. Karakteristik mutu biji kakao (Theobroma cacao L) dengan perlakuan waktu fermentasi berdasar SNI 23232008. Jurnal Industri Hasil Perkebunan 12(1): 34-42.

Beckett, S. T., Fowler, M., Ziegler, G. R. 2017. Beckett's industrial chocolate manufacture and use. John Wiley \& Sons, Chichester, West Sussex, UK.

Dewi, L. C., Susanto, W. H., Maligan, J. M. 2015. Penanganan pasca panen kelapa sawit (penyemprotan dengan natrium benzoat dan kalium sorbat terhadap mutu CPO). Jurnal Pangan dan Agroindustri 3(2): 489498.

Gu, F., Tan, L., Wu, H., Fang, Y., Xu, F., Chu, Z., Wang, Q. 2013. Comparison of cocoa from China, Indonesia and Papua New Guinea. Journal of Foods 2: 183-197.

Haryadi dan Supriyanto. 2012. Teknologi kakao. In Teknologi cokelat (p. 56). Cetakan pertama. Gadjah Mada University Press. Yogyakarta.

Hayati, R., Yusmanizar., Mustafril dan Fauzi, H. 2012. Kajian fermentasi dan suhu pengeringan pada mutu kakao (theobroma 
cacao l.). Jurnal Keteknikan Pertanian 26(2): 129-135.

Ketaren, S. 2008. Pengantar Teknologi Minyak Dan Lemak Pangan. Universitas Indonesia Press. Jakarta.

Liyanda, M., Karim, A., dan Abubakar, Y. 2012. Analisis kriteria kesesuaian lahan terhadap produksi kakao pada tiga klaster pengembangan di Kabupaten Pidie.Jurnal Agrista 16(2): 62-79.

Maimun, T., Arahman, N., Hasibuan, F. A., dan Rahayu, P. 2017. Penghambatan peningkatan kadar asam lemak bebas (free fatty acid) pada buah kelapa sawit dengan menggunakan asap cair. Jurnal Teknologi dan Industri Pertanian Indonesia 9(2): 4449.

Manalu, LP., Abdullah, K., Sumarsono, M., dan Setiawan, BI. 1998. Pengeringan kakao memakai pengering surya dengan pengaduk mekanis. Buletin Keteknikan Pertanian 12(3): 32-42.

Misnawi., Jinap, S., Jamilah, B., and Nazamid, S. 2002. Oxidation of polyphenols in unfermented and partly fermented cocoa beans by cocoa polyphenol oxidase and tyrosinase. Journal of the Science of Food and Agriculture 82(5): 559-566.

Mulato, S., Widyatomo, S., Misnawi, \& Suharjono, E. 2010. Pengolahan Produk Primer dan Sekunder. Puslitkoka. Jember.

Nainggolan, S.R.M., Tamrin, Warji, dan Lanya, B. 2013. Uji kinerja alat pengering tipe Batch skala lab untuk pengeringan gabah dengan menggunakan bahan bakar sekam padi. $J$ Teknik Pertanian Lampung 2(3): 161172.
Pahan, Iyung. 2015. Panduan lengkap kelapa sawit (manajemen agribisnis dari hulu ke hilir). Penebar Swadaya. Jakarta.

Puziah, H.S., 2005. Cocoa Fermentation. Pusat Penelitian Kopi dan Kakao Indonesia, Jember.

Rahmadewi, YM., dan Darmadji, P. 2019. Evaluasi sensoris coklat batang dari biji kakao rakyat dengan kondisi fermentasi dan pengeringan yang berbeda. Jurnal Dunia Gizi 2(1): 56-62.

Ramlah, Sitti. 2016. Karakteristik mutu dan citarasa cokelat kaya polifenol. Jurnal Industri Hasil Perkebunan 11(1): 23-32.

Ristanti, E. Y., Suprapti, Anggraeni, D. 2016. Karakteristik komposisi asam lemak pada biji kakao dari 12 daerah di sulawesi selatan. Jurnal Industri Hasil Perkebunan 11(1): 15-22.

Utami, R. R. 2018. Antioksidan biji kakao: pengaruh fermentasi dan penyangraian terhadap perubahannya. Jurnal Industri Hasil Perkebunan 13(2): 75-85.

Warianti dan Darmanto. 2019. Analisis laju penurunan kadar air pada pengeringan benih di dalam dryer box. Jurnal Keteknikan Pertanian Tropis dan Biosistem 7(2): 203211.

Widyotomo, S., Mulato, S., \& Handaka. 2004. Mengenal Lebih Dalam Teknologi Pengolahan Biji Kakao. Warta Litbang Pertanian 26: 5-6.

Wahyudi, T.T.R, Panggabean, Pujiyanto (editor). 2013. Kakao, Manajemen Agribisnis dari Hulu ke Hilir. Penebar Swadaya. 